Research article

\title{
Finger millet (Eleusine coracana L.) grain yield and yield components as influenced by phosphorus application and variety in Western Kenya
}

\author{
Wekha N. Wafula ${ }^{1}$, Korir K. Nicholas ${ }^{1}$, Ojulong F. Henry ${ }^{2}$, \\ Moses Siambi ${ }^{2}$ and Joseph P. Gweyi-Onyango ${ }^{1}$ \\ ${ }^{1}$ Department of Agricultural Science and Technology, Kenyatta University, PO Box 43844-00100 Nairobi, Kenya \\ ${ }^{2}$ ICRISAT, ICRAF house, UN Avenue, Gigiri, PO BOX 39063-00623, Nairobi, Kenya
}

*Corresponding Author: nelwaf@gmail.com

[Accepted: 15 December 2016]

\begin{abstract}
Finger millet is one of the potential cereal crops that can contribute to the efforts of realization of food security in the Sub-Saharan Africa. However, scientific information available with regards to improving soil phosphorus supply and identification of $\mathrm{P}$ efficient varieties for the crops potential yield is limited. In order to investigate the effects of $\mathrm{P}$ levels on yield components and grain yield On-station field experiments were conducted in two sites of western Kenya during the long and short rain seasons of 2015. The experiment was laid out in a Randomized Complete Block Design in factorial arrangement with four levels of $\mathrm{P}\left(0,12.5,25\right.$ and $37.5 \mathrm{~kg} \mathrm{P}_{2} \mathrm{O}_{5}$ ha $^{-1}$ and three finger millet varieties (U-15, P-224 and a local check-Ikhulule) and the treatments replicated three times. The increase of phosphorus levels significantly $(\mathrm{P} \leq 0.05)$ increased the grain yield over the control up to $25 \mathrm{~kg} \mathrm{P}_{2} \mathrm{O}_{5} \mathrm{ha}^{-1}$ during the long rain seasons and $25 \mathrm{~kg} \mathrm{P}_{2} \mathrm{O}_{5} \mathrm{ha}^{-1}$ during the short rain seasons in both sites. Interactions at $\mathrm{P} \leq 0.05$ were revealed on the grain yield where improved variety P-224 at $25 \mathrm{~kg} \mathrm{P}_{2} \mathrm{O}_{5}$ ha $^{-1}$ produced the highest grain yield of 4.74 t.ha $^{-1}$ in Alupe and 4.77 tha $^{-1}$ in Kakamega and the consistent results suggest that the combination is highly recommended. Therefore the use of judicious and proper rates of $\mathrm{P}$ fertilizers can markedly increase the grain yield of finger millet in western Kenya.
\end{abstract}

Keywords: Finger millet - Potential cereal - Food security - Phosphorus supply - Judicious.

[Cite as: Wafula WN, Nicholas KK, Henry OF, Siambi M \& Gweyi-Onyango JP (2016) Finger millet (Eleusine coracana L.) grain yield and yield components as influenced by phosphorus application and variety in Western Kenya. Tropical Plant Research 3(3): 673-680]

\section{INTRODUCTION}

Finger millet (Eleusine coracana L. Geartn) belongs to family Poaceae and is one of the most important food cereals in the Sub-Saharan Africa. Indigenous to the highlands of Uganda and Ethiopia, finger millet is widely produced by small scale landholders and consumed locally (Adugna et al. 2011). The crop possesses greater impact on the poor in Africa through the provision of food security and economic growth. Its grains can be stored for several years in local storage conditions without damage by insect pests and this cushion against vulnerability to unpredictable famine and drought. It is well adapted to heat, drought and poor soil stress that prevail in marginal and degraded soils (Okalebo et al. 1990) and has a relatively better nutritional value with high calcium content as well as crucial amino acids that are deficient in most cereals. These attributes plus its high market value compared to other cereals makes finger millet one of the salient crops among resource poor communities living in food insecure areas (NRC 1996). The cultivation of the crop covers around 65,000 ha in Kenya with an average yield of 1 tha $^{-1}$ which is below the potential as observed in other parts of the world like in India where between 5-6 kg.ha ${ }^{-1}$ were realized under ideal irrigated conditions (Oduori 2005, NRC 1996).

One of the main problems faced by the farmers is inherent low soil $\mathrm{P}$ and degradation due to continued cultivation. Notwithstanding the importance of finger millet, the research attention given to the crop has been 
limited and the information is scarce on the $\mathrm{P}$ management of the crop. Phosphorus is an essential nutrient for the life of plants whereby without adequate supply plants cannot reach their maximum yield. Adoption of proper agronomic management practices to existing varieties can lead to achieving potential yields. Therefore, it is necessary to know the optimum dose of the $\mathrm{P}$ fertilizer to be applied for maximum yields without compromising the environment. Thus, the present study was conducted to determine the effect of phosphorus fertilizer rates on the yield components and grain yield of finger millet in the western region of Kenya where most of the crop is grown.

\section{MATERIALS AND METHODS}

Study area

Two On-station experiments were conducted in the crops research stations in Kakamega and Busia Counties. The Kenya Agricultural and Livestock Research Organization (KALRO)-Kakamega lies on Longitude $4^{\circ} 45^{\prime} 0^{\prime \prime}$ E and Latitude $0^{\circ} 16^{\prime} 60^{\prime \prime} \mathrm{N}$ with an elevation of 1523 metres above sea level. The soils were predominantly sandy loam (53.55\% sand, 32.18\% silt and 14.27\% clay). The Kenya Agricultural and Livestock Research Organization (KALRO)-Alupe lies within latitude $0^{\circ} 30^{\prime \prime} \mathrm{N}$ and Longitude $34^{\circ} 07^{\prime} 50^{\prime \prime}$ E with an elevation of 1157 metres above sea level. The soils were sandy loam with $47.57 \%$ sand, $35.76 \%$ silt/loam and $16.67 \%$ clay. The two sites have two growing seasons in a calendar year between March and August termed the long rain season and between September and December which is termed the short rain season. The experiment was carried out in the two seasons of 2015.

\section{Experimental design and treatments}

The experiments were laid out in Randomized Complete Block Design in factorial arrangement with two factor sets of four levels of $\mathrm{P}\left(\mathrm{P}_{0}=\right.$ Control, $\mathrm{P}_{1}=12.5 \mathrm{~kg} \cdot \mathrm{ha}^{-1} \mathrm{P}_{2} \mathrm{O}_{5}, \mathrm{P}_{2}=25 \mathrm{~kg} \cdot \mathrm{ha}^{-1} \mathrm{P}_{2} \mathrm{O}_{5}$ and $\left.\mathrm{P}_{3}=37.5 \mathrm{~kg} \cdot \mathrm{ha}^{-1} \mathrm{P}_{2} \mathrm{O}_{5}\right)$ and three varieties (U-15, P-224 and Ikhulule). Ikhulule was the local check variety and no phosphorus applied for the control. Each treatment was replicated three times while the other cultural practices were kept constant with a blanket application of $\mathrm{N}\left(50 \mathrm{~kg} \cdot \mathrm{ha}^{-1} \mathrm{~N}\right)$ at four weeks after emergence.

\section{Land management and cultural operations}

Analysis of composite surface soil samples collected from the experimental fields indicated the soils were moderately acidic ( $\mathrm{pH}$ in 1:2.5 soil: water ratio of 5.45 in Alupe and 5.60 in Kakamega). The top soils were moderately low in Total N (0.12\% in Alupe and 0.18\% in Kakamega), high in organic carbon (2.26\% in Alupe and $3.40 \%$ in Kakamega), low in Olsen extractable P (6 ppm in Alupe and 5 ppm in Kakamega), and moderate in available $\mathrm{K}$ contents $(0.30 \%$ in Alupe and $0.75 \%$ in Kakamega).

Land preparation was done prior to the onset of rains during both seasons. Planting was done by hand drilling seeds obtained from ICRISAT in rows spaced $40 \mathrm{~cm}$ between rows and later thinned after four weeks between plants to an intra-row spacing of $10 \mathrm{~cm}$. Phosphorus fertilizer was applied wholly by hand drilling at planting according to the treatments as Triple Superphosphate (TSP). All other agronomic operations were done as recommended for the crop. Harvesting on the net plot was done when the fingers had achieved $90 \%$ brown color.

\section{Data collection and analysis}

The finger length of the longest spike from at least five main tillers from each plot was measured and the average recorded. The finger width was measured across the center of the longest five spikes from each plot and the average recorded. The number of grains per spikelets was counted at dough stage after removing five spikelets from the middle portion of the rachis of five main tillers in each plot and the average recorded. The number of panicles per finger was counted at dough stage on the main ears of five plants and the average recorded. The grain yield from the net plot of every experimental unit $\left(3 \mathrm{~m}^{2}\right)$ was weighed on a Tronix Avery digital scale at $13 \%$ moisture content and extrapolated to yield per hectare.

Analysis of variance (ANOVA) was carried out for the grain yield data collected following statistical procedures appropriate for the design using SAS computer software. Whenever significant differences between treatments were observed, the means were separated using Fisher's Protected LSD at 5\% probability. Regression analysis was carried out to estimate the relationship between the grain yields as influenced by the applied phosphorus fertilizer.

\section{RESULTS AND DISCUSSION}


Influence of phosphorus and variety on yield and yield components

Phosphorus did not have a significant role on the finger length and width in both sites for both seasons (Table 1). However, numerically the control had the shortest fingers in Kakamega for both seasons and in Alupe during the long rain season. The varieties had significant differences $(\mathrm{P} \leq 0.05)$ for both seasons in Kakamega and Alupe where P-224 had the longest fingers (spikes). Similarly, the widest fingers were observed on variety $\mathrm{P}-224$ in both sites for both seasons. The interaction between phosphorus application levels and variety was only revealed on the finger width in Kakamega during the long rain season where P-224 at $12.5 \mathrm{~kg}^{-h a}{ }^{-1} \mathrm{P}_{2} \mathrm{O}_{5}$ had the widest fingers with $1.189 \mathrm{~cm}$.

Table 1. The influence of phosphorus and variety on the finger length and width (cm) in Alupe and Kakamega.

\begin{tabular}{|c|c|c|c|c|c|c|c|c|}
\hline \multirow{3}{*}{$\begin{array}{c}\text { Fertilizer } \\
\text { Level }\end{array}$} & \multicolumn{4}{|c|}{ Finger Length (cm) } & \multicolumn{4}{|c|}{ Finger Width $(\mathrm{cm})$} \\
\hline & \multicolumn{2}{|c|}{ Kakamega } & \multicolumn{2}{|c|}{ Alupe } & \multicolumn{2}{|c|}{ Kakamega } & \multicolumn{2}{|c|}{ Alupe } \\
\hline & 2015 SR & 2015 LR & 2015 SR & 2015 LR & 2015 SR & 2015 LR & 2015 SR & 2015 LR \\
\hline 0 & $6.7 \mathrm{a}$ & $5.3 \mathrm{a}$ & $7.9 \mathrm{a}$ & $7.7 \mathrm{a}$ & $1.00 \mathrm{a}$ & $1.05 \mathrm{a}$ & $1.20 \mathrm{a}$ & $1.10 \mathrm{a}$ \\
\hline 12.5 & $6.8 \mathrm{a}$ & $5.7 \mathrm{a}$ & $7.7 \mathrm{a}$ & $8.0 \mathrm{a}$ & $0.98 \mathrm{a}$ & $1.06 \mathrm{a}$ & $1.11 \mathrm{a}$ & $1.09 \mathrm{a}$ \\
\hline 25.0 & $6.8 \mathrm{a}$ & $5.9 \mathrm{a}$ & $8.3 \mathrm{a}$ & $8.1 \mathrm{a}$ & $0.99 a$ & $1.02 \mathrm{a}$ & $1.1 \mathrm{a}$ & $1.10 \mathrm{a}$ \\
\hline 37.5 & $6.7 \mathrm{a}$ & $5.8 \mathrm{a}$ & $7.8 \mathrm{a}$ & $8.2 \mathrm{a}$ & $0.98 \mathrm{a}$ & $1.03 \mathrm{a}$ & $1.09 \mathrm{a}$ & $1.08 \mathrm{a}$ \\
\hline F pr. & 0.928 & 0.211 & 0.671 & 0.175 & 0.836 & 0.71 & 0.427 & 0.856 \\
\hline $\operatorname{LSD}(0.05)$ & 0.650 & 0.750 & 0.993 & 0.504 & 0.061 & 0.058 & 0.155 & 0.046 \\
\hline \multicolumn{9}{|l|}{ Variety } \\
\hline $\mathrm{U}-15$ & $6.6 b$ & $5.5 b$ & $8.4 \mathrm{a}$ & $8.2 \mathrm{~b}$ & $0.94 b$ & $0.98 b$ & $1.12 \mathrm{~b}$ & $1.01 \mathrm{~b}$ \\
\hline $\mathrm{P}-224$ & $7.3 \mathrm{a}$ & $6.4 \mathrm{a}$ & $8.5 \mathrm{a}$ & $9.0 \mathrm{a}$ & $1.04 \mathrm{a}$ & $1.10 \mathrm{a}$ & $1.18 \mathrm{a}$ & $1.15 \mathrm{a}$ \\
\hline Ikhulule & $6.3 b$ & $5.1 \mathrm{~b}$ & $6.89 \mathrm{~b}$ & $6.9 \mathrm{c}$ & $0.99 \mathrm{~b}$ & $1.04 \mathrm{~b}$ & $1.08 \mathrm{c}$ & $1.11 \mathrm{a}$ \\
\hline F pr. & 0.003 & $\leq .001$ & 0.001 & $\leq .001$ & 0.003 & 0.002 & 0.036 & $\leq .001$ \\
\hline $\operatorname{LSD}(0.05)$ & 0.560 & 0.685 & 0.860 & 0.437 & 0.053 & 7.300 & 0.035 & 0.040 \\
\hline $\mathrm{CV} \%$ & 9.8 & 10 & 12.8 & 6.4 & 6.3 & 7.3 & 14.1 & 4.3 \\
\hline \multicolumn{9}{|l|}{ Interaction } \\
\hline $\mathrm{P} \times \mathrm{V}$ & NS & NS & NS & NS & NS & $*$ & NS & NS \\
\hline
\end{tabular}

Note: Means within a column followed by different letter ( $\mathrm{s}$ ) are significantly different at $\mathrm{P} \leq 0.05$. LR=Long rain season; $\mathrm{SR}=$ Short rain season; $* *=$ Significant at $\mathrm{P} \leq 0.05$; NS=Not significant at $\mathrm{P} \leq 0.05$

Table 2. Effect of phosphorus levels on the number of fingers per panicle and grains per spikelet in Alupe and Kakamega.

\begin{tabular}{|c|c|c|c|c|c|c|c|c|}
\hline \multirow{3}{*}{$\begin{array}{c}\text { Fertilizer } \\
\text { Level }\end{array}$} & \multicolumn{4}{|c|}{ Fingers per panicle } & \multicolumn{4}{|c|}{ Grains per spikelet } \\
\hline & \multicolumn{2}{|c|}{ Kakamega } & \multicolumn{2}{|c|}{ Alupe } & \multicolumn{2}{|c|}{ Kakamega } & \multicolumn{2}{|c|}{ Alupe } \\
\hline & 2015 SR & 2015 LR & 2015 SR & 2015 LR & $2015 \mathrm{SR}$ & 2015 LR & $2015 \mathrm{SR}$ & 2015 LR \\
\hline 0 & $6 a$ & $7 \mathrm{~b}$ & $7 \mathrm{~b}$ & $7 \mathrm{c}$ & $8 \mathrm{a}$ & $7 \mathrm{~b}$ & $7 \mathrm{a}$ & $7 \mathrm{a}$ \\
\hline 12.5 & $6 a$ & $7 b$ & $8 \mathrm{a}$ & $9 \mathrm{a}$ & $8 \mathrm{a}$ & $8 \mathrm{a}$ & $7 \mathrm{a}$ & $7 a$ \\
\hline 25 & $6 a$ & $8 a$ & $8 \mathrm{a}$ & $8 b$ & $8 \mathrm{a}$ & $8 \mathrm{a}$ & $7 \mathrm{a}$ & $7 \mathrm{a}$ \\
\hline 37.5 & $6 a$ & $8 \mathrm{a}$ & $8 \mathrm{a}$ & $9 \mathrm{a}$ & $8 \mathrm{a}$ & $7 \mathrm{~b}$ & $7 \mathrm{a}$ & $7 \mathrm{a}$ \\
\hline F pr. & 0.834 & 0.043 & 0.022 & 0.003 & 0.51 & 0.007 & 0.799 & 0.128 \\
\hline LSD (0.05) & 0.500 & 0.842 & 0.558 & 0.531 & 1.000 & 0.543 & 0.544 & 0.576 \\
\hline \multicolumn{9}{|l|}{ Variety } \\
\hline U-15 & $7 \mathrm{a}$ & $8 \mathrm{a}$ & $8 \mathrm{a}$ & $9 a$ & $8 \mathrm{a}$ & $7 \mathrm{~b}$ & $6 \mathrm{~b}$ & $6 \mathrm{~b}$ \\
\hline P-224 & $7 \mathrm{a}$ & $7 b$ & $8 a$ & $8 b$ & $8 a$ & $8 a$ & $7 \mathrm{a}$ & $7 \mathrm{a}$ \\
\hline Ikhulule & $6 \mathrm{~b}$ & $7 \mathrm{~b}$ & $7 \mathrm{~b}$ & $8 \mathrm{~b}$ & $8 \mathrm{a}$ & $7 b$ & $6 \mathrm{~b}$ & $6 \mathrm{~b}$ \\
\hline F pr. & 0.036 & 0.002 & $\leq .001$ & 0.005 & 0.497 & 0.037 & $\leq .001$ & 0.004 \\
\hline LSD (0.05) & 0.500 & 0.448 & 0.483 & 0.460 & 0.800 & 0.541 & 0.471 & 0.499 \\
\hline $\mathrm{CV} \%$ & 9 & 14.4 & 7.3 & 6.6 & 12.2 & 7.4 & 8.4 & 9 \\
\hline \multicolumn{9}{|l|}{ Interaction } \\
\hline $\mathrm{P} \times \mathrm{V}$ & NS & NS & NS & NS & NS & NS & NS & NS \\
\hline
\end{tabular}

Note: Means within a column followed by different letter (s) are significantly different at $\mathrm{P} \leq 0.05$. LR=Long rain season; $\mathrm{SR}=$ Short rain season; $* *=$ Significant at $\mathrm{P} \leq 0.05$; NS=Not significant at $\mathrm{P} \leq 0.05$

Application of phosphorus fertilizer led to increased number of fingers per panicle for both seasons in Alupe and Kakamega during the long rain season compared to the control (Table 2). The highest number of fingers per panicle was observed during the long rain season in Kakamega with a mean of nine fingers per panicle (head). The number of grains in a spikelet only showed significant differences $(\mathrm{P} \leq 0.05)$ during the long rain season in Kakamega where the 12.5 and $25.0 \mathrm{~kg} \cdot \mathrm{ha}^{-1} \mathrm{P}_{2} \mathrm{O}_{5}$ treatments had the highest while the control and the highest rate 
had the lowest as shown in table 2 . The number of fingers per panicle and grains per spikelet varied significantly $(\mathrm{P} \leq 0.05)$ among the varieties in both sites for both seasons. U-15 showed the highest number of fingers per panicle in both sites for both seasons while P-224 had the highest number of grains per spikelet for both seasons across the sites.

\section{Interactive effect of phosphorus and variety on grain yield}

The interaction between variety and phosphorus fertilizer exerted significant influence $(\mathrm{P} \leq 0.05)$ on the grain yield for both seasons in both sites (Fig. 1). In Alupe during the long rain season, improved variety P-224 at a phosphate rate of $25 \mathrm{~kg} \cdot \mathrm{ha}^{-1} \mathrm{P}_{2} \mathrm{O}_{5}$ had significantly $(\mathrm{P} \leq 0.05)$ the highest yield of $4.738 \mathrm{t}^{-h a^{-1}}$ while the local variety Ikhulule with the highest rate had the lowest grain yield of 2.993 t.ha ${ }^{-1}$. At $12.5 \mathrm{~kg} \cdot \mathrm{ha}^{-1} \mathrm{P}_{2} \mathrm{O}_{5}$, the local variety Ikhulule showed the highest grain yield of 4.549 t.ha $^{-1}$. Variety U-15 had the highest grain yield on the $25 \mathrm{~kg} \cdot \mathrm{ha}^{-1} \mathrm{P}_{2} \mathrm{O}_{5}$ rate of 4.172 t.ha $^{-1}$. The lowest grain yield in the improved varieties was observed on the control. The same pattern shown in the long rain season of the highest yielding combination was observed in the short rain season with 3.695 t.ha $^{-1}$. The grain yield was however generally lower compared to the long rain season (Fig. 1). Variety U-15 showed the highest grain yield on the $25 \mathrm{~kg} \cdot \mathrm{ha}^{-1} \mathrm{P}_{2} \mathrm{O}_{5}$ rate while the local variety Ikhulule had the highest grain yield on the two highest rates. The lowest grain yield among the varieties was observed on the control.

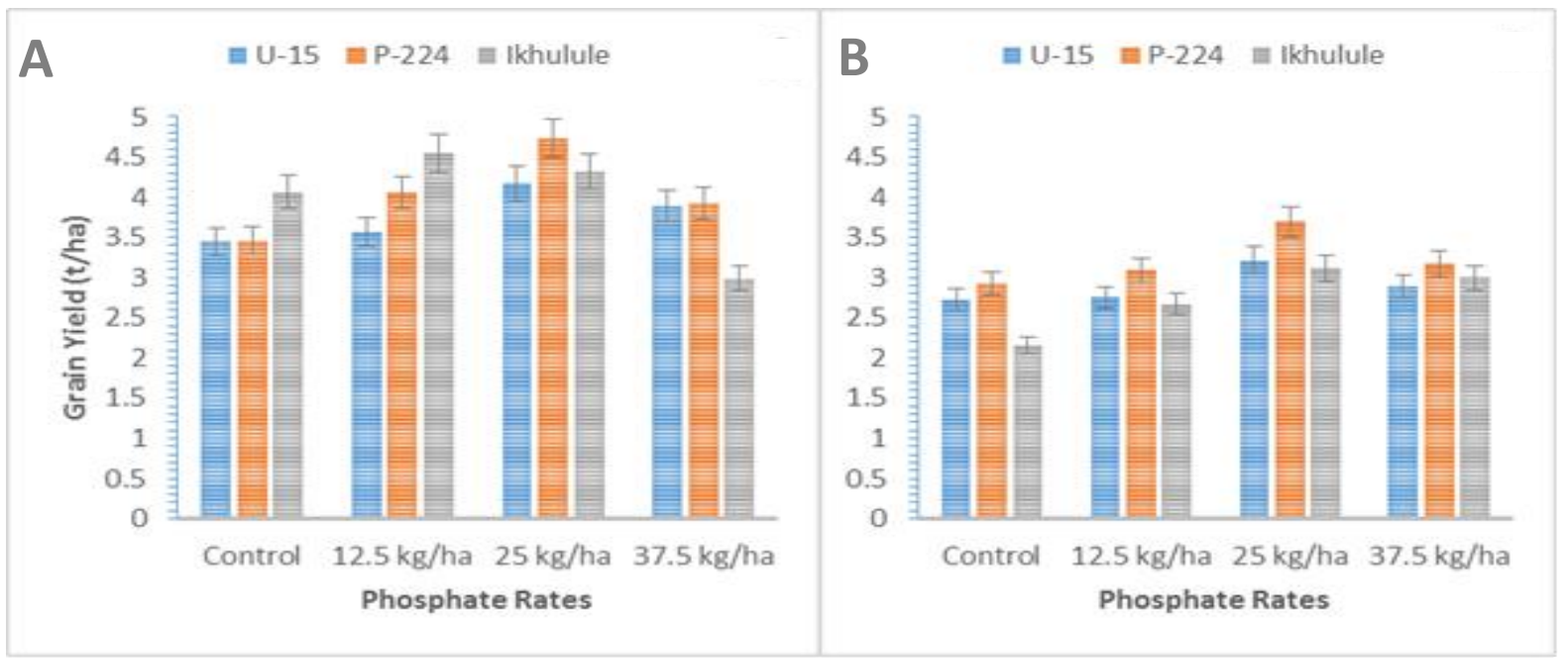

Figure 1. The influence of variety and phosphorus fertilizer on the grain yield of finger millet in Alupe during the long (A) and short (B) rain seasons.

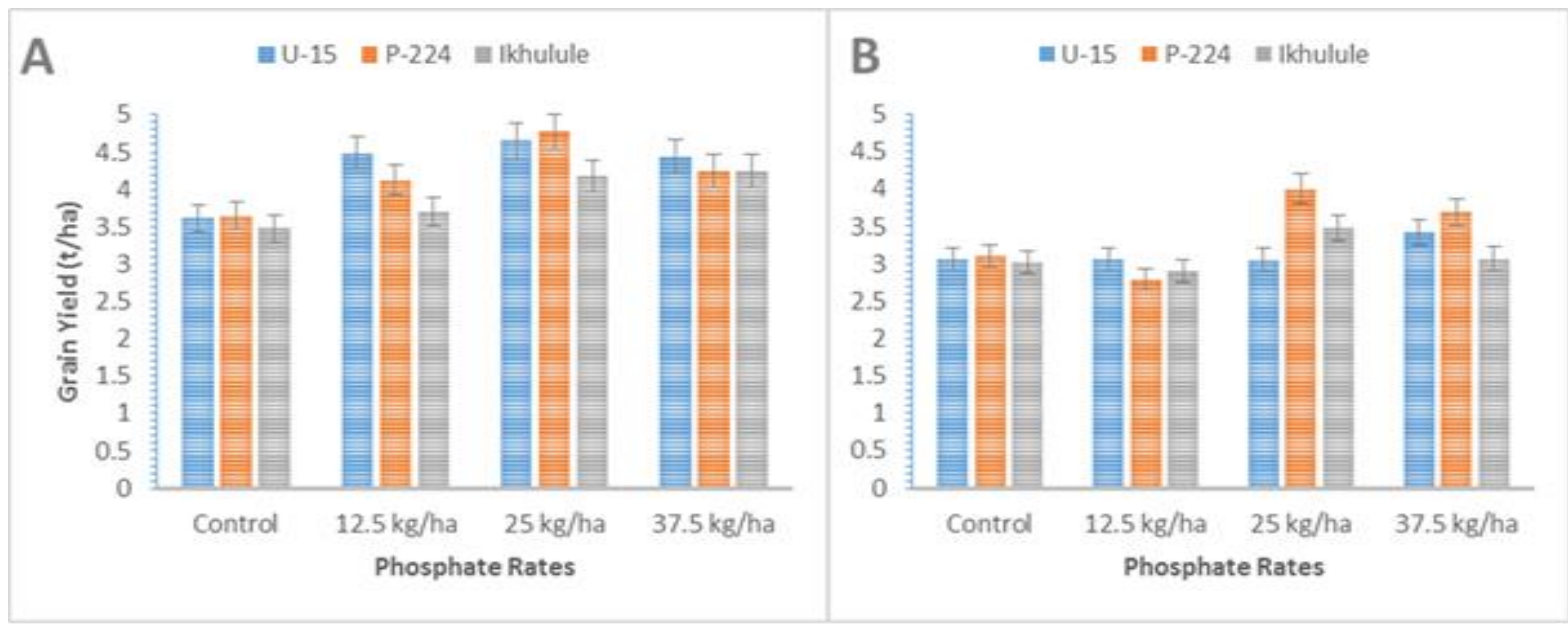

Figure 2. The influence of variety and phosphorus fertilizer on the grain yield of finger millet in Kakamega during the long (A) and short (B) rain seasons.

In Kakamega during the long rain season significant interactions $(\mathrm{P} \leq 0.05)$ between variety and phosphorus fertilizer were observed where variety P-224 showed the highest yield at $25 \mathrm{~kg} \cdot \mathrm{ha}^{-1} \mathrm{P}_{2} \mathrm{O}_{5}\left(4.770 \mathrm{t} \cdot \mathrm{ha}^{-1}\right)$ as well as variety U-15 (4.650 t.ha ${ }^{-1}$ ) which was however insignificantly different from that at $12.5 \mathrm{~kg} \cdot \mathrm{ha}^{-1} \mathrm{P}_{2} \mathrm{O}_{5}$ rate and the highest rate (Fig. 2). The local variety Ikhulule had the highest grain yield at the highest rates of phosphorus 
fertilizer as observed in the short rain season in Alupe. Irrespective of the varieties, the lowest grain yield was observed in the control. In the short rain season, the highest grain yield $\left(4.0 \mathrm{t}^{-\mathrm{ha}^{-1}}\right)$ was observed on variety $\mathrm{P}$ 224 at the $25 \mathrm{~kg} \cdot \mathrm{ha}^{-1} \mathrm{P}_{2} \mathrm{O}_{5}$ rate while the same variety had the least grain yield on the $12.5 \mathrm{~kg} \cdot \mathrm{ha}^{-1} \mathrm{P}_{2} \mathrm{O}_{5}$ rate and the control. The local variety Ikhulule showed the highest grain yield at the $25 \mathrm{~kg} \cdot \mathrm{ha}^{-1} \mathrm{P}_{2} \mathrm{O}_{5}$ while improved variety U-15 showed the highest grain yield at the highest rate of phosphorus fertilizer (Fig. 2).

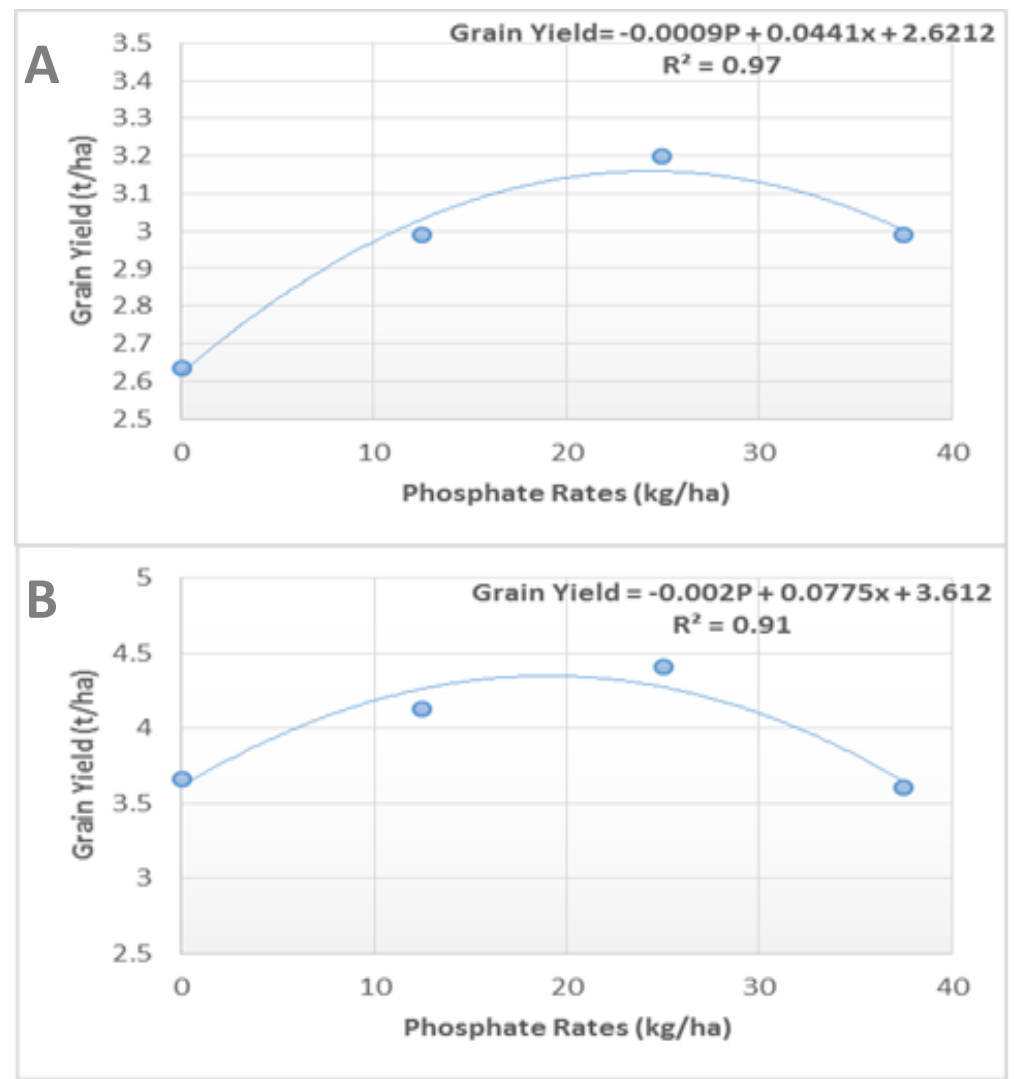

Figure 3. Mean grain yield as a polynomial function of phosphate rates for finger millet during the short (A) and long (B) rain seasons in Alupe.
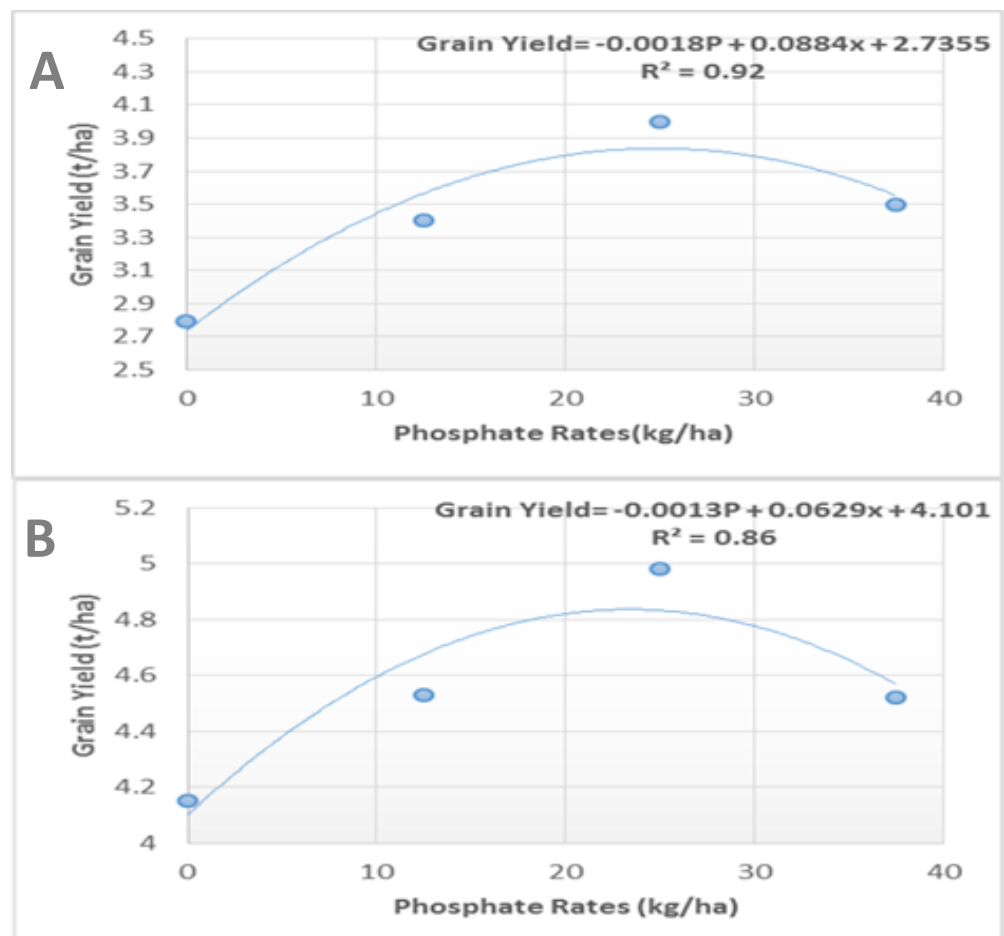

Figure 4. Polynomial regression characterizing the relationship between the grain yield response of finger millet varieties to applied phosphorus fertilizer in Kakamega during the short (A) and long (B) rain seasons. 
The influence of phosphorus was significant $(\mathrm{P} \leq 0.05)$ on the finger millet varieties grain yield for both seasons in the two sites. In Alupe, grain yield significantly increased from 2.6 t.ha $^{-1}$ on the control to 3.2 t.ha ${ }^{-1}$ with an increase in the level of phosphorus fertilizer up to $25 \mathrm{~kg}_{\mathrm{gha}}{ }^{-1}$ and started decreasing with further increase as shown in figure 3 during the short rains season. During the long rain season, the increase of phosphorus fertilizer up to $20 \mathrm{~kg} \cdot \mathrm{ka}^{-1}$ showed significantly $(\mathrm{P} \leq 0.05)$ the highest grain yield with a $20.56 \%$ increase over the control. During the same period, the highest rate and the control elicited the lowest grain yield (Fig. 3). In Kakamega, a linear trend was observed with the increment of the phosphorus fertilizer dose up to $25 \mathrm{~kg}^{-\mathrm{ha}^{-1}}$ and thereafter decreased in the short rain season while in the long rain season an increase of up to $20 \mathrm{~kg}^{-\mathrm{ha}^{-1}}$ showed the peak on the grain yield and a drop followed thereafter. The highest yield of 4.0 t.ha $^{-1}$ was observed during the short rain season and 4.98 tha $^{-1}$ in the long rain season while the control had the lowest grain yield for both seasons (Fig. 4).

\section{DISCUSSION}

The numerical increase in the finger length in Kakamega is probably to the enhanced metabolic processes due to optimum phosphorus and lack of reduced metabolic activity. However, the insignificant response to applied P might be due to the optimal availability of $\mathrm{N}$ and supplement of Urea during study period which led to the luxurious vegetative growth and induced the hidden P hunger. Similar findings were reported by Dixon (2003) who found that in low soil P, foliar application of P only corrected the deficiencies and maintained higher yields but did not increase the spike length or width of winter wheat due to excessive application and availability of nitrogen. The increase in the number of fingers per panicle was due to the synthesis of amino acid and chlorophyll and better carbohydrates transformation which resulted in better growth and a higher number of panicles which ultimately produced more number of grains per spikelet. These findings were in conformity with that by Parmer (2007) who observed an increase in the number of spikes per head due to an increase of phosphorus up to $100 \mathrm{~kg} \mathrm{P}_{2} \mathrm{O}_{5}$ per hectare of super phosphate in Tuberose $\mathrm{Cv}$. Double. The improved varieties produced higher number of grains per spikelet during the same period due to their ability to respond positively to applied phosphorus through efficient utilization and also due to their genetic potential. Similar spikelet count differences among rice varieties were reported by Obaidullah (2007).

The positive response of finger millet varieties on the applied $\mathrm{P}$ was due to the low available tested $\mathrm{P}$ in the study soils. It has also been reported that in many parts of western Kenya P stress is a major limiting nutrient and also the response of other nutrients is usually inhibited under this limitation (Opiyo 2004). Phosphorus efficiency of the identified variety P-224 was probably due to its genetic ability to produce high yield per unit $\mathrm{P}$ acquired. Ozturk (2005) reported that the identification of $\mathrm{P}$ efficient varieties with great ability to grow and yield in soil with limited phosphorus supply and efficiently use applied P improves the sustainability of crop production. This reduces the production cost for the small holder farmers which is associated with high $\mathrm{P}$ applications and minimizes environmental pollution resulting from run-off of excess $P$ fertilizer. The capacity for P uptake has been documented to be affected by several environmentally or genetically controlled factors that differ among varieties (Pearse et al. 2006). Pearse et al. (2006) also introduced a model that roots in some varieties have a positive effect on $\mathrm{P}$ uptake, which enhances $\mathrm{P}$ status and efficiency. Different varieties have inherent differences in the maximum growth rate and $\mathrm{P}$ uptake which leads them to differ in their productivity (Shen et al. 2005). Ren et al. (2007) also found that different species of ryegrass with inherent low growth rates accumulated higher levels of phosphorus in their shoots at low P-levels which led to lower grain yields probably due to reduced efficiency of $\mathrm{P}$ for grain filling. The difference in $\mathrm{P}$ uptake among the genotypes showed the diversity in efficiency with which plants are able to absorb $\mathrm{P}$ from soils with varying $\mathrm{P}$ availability (Hinsinger 2009). During the short rain season in Kakamega the control had the same grain yield as the $12.5 \mathrm{~kg}^{-h^{-1}} \mathrm{P}_{2} \mathrm{O}_{5}$ rate and it is probably due to the availability of phosphorus that was earlier in its organic form. Organic forms of $\mathrm{P}$ are found in humus and other organic material (Masinde et al. 2009). Phosphorus in organic material is released by a mineralization process involving soil organisms (Shen et al. 2005) and thus the increased growth on the control as that of mildly P applied treatment.

The increase in grain yield was probably due to the positive influence of phosphorus in initiation and growth of roots that in turn sped up and increased the uptake of essential elements and moisture from the soil. Supply of optimal phosphorus also ensured that the plants inhibited the formation of excess roots that would have led to the excessive loss of carbon from the plants rooting system and reducing the efficiency in energy production (Shane \& Lambers 2005). Several investigators have reported the same findings that either initiation or www.tropicalplantresearch.com 
inhibition of root formation is linked to internal $\mathrm{P}$ concentration, uptake and availability in the soil and significantly influences the productivity of crops (Li \& Liang 2005, Shen et al. 2005). Alam et al. (2003) also reported similar findings that the application of phosphorus fertilizer (SSP) to wheat crop significantly increased the grain yield as well as P-uptake over control. A limited supply of P reduces leaf area and therefore reducing the supply of photosynthates to the grain and subsequently reducing the grain filling. Optimal phosphorus also increased the synthesis of cytokinins which enhanced the flowering process that supported the higher formation of grains. Various scientists (Rehman et al. 2006, Yousaf 2004) have also reported that appropriate and balanced phosphorus fertilization on wheat and rice not only caused grain yield enhancement but also had a positive impact on phosphorus and another nutrient uptake by these crops. Finger millet varieties efficiency on the use of available phosphorus might also be due to the plants mechanism to secrete phosphatases which are key drivers of rhizosphere activities that influenced $\mathrm{P}$ uptake. These chemical and biological processes in the rhizosphere determine the mobilization and acquisition of soil nutrients, microbial dynamics, and controls nutrient use efficiency of crops, thus profoundly influencing crops productivity (Hinsinger 2009, Richardson et al. 2009, Wissuwa et al. 2009). Optimal availability of $\mathrm{P}$ resulted in an in increase of nutrient use efficiency by the provision of adequate energy and an early proliferation of growth attributes which increased the grain yield potential.

\section{CONCLUSION}

Application of phosphorus affected positively the productivity of the finger millet varieties in Kakamega and Alupe for both seasons. An increase of more than $20 \%$ was observed on the $20 \mathrm{~kg} \cdot \mathrm{ha}^{-1} \mathrm{P}_{2} \mathrm{O}_{5}$ rate during the long rain seasons in both sites and at $25 \mathrm{~kg} \cdot \mathrm{ha}^{-1} \mathrm{P}_{2} \mathrm{O}_{5}$ in the short rain seasons. The maximum yield was achieved under the improved variety in both sites due to its superiority in efficiency in utilizing applied phosphorus fertilizer and superior yield attributes. The application of phosphorus fertilizer beyond $25 \mathrm{~kg} \cdot \mathrm{ha}^{-1} \mathrm{P}_{2} \mathrm{O}_{5}$ was found to be detrimental to finger millet grain yield in the study regions of Kenya.

\section{ACKNOWLEDGEMENT}

The authors are grateful to the International Crops Research Institute for the Semi-Arid Tropics (ICRISAT)Nairobi for the financial support. The Kenya Agricultural and Livestock Research Organization and ICRISAT staff in Kakamega and Alupe are also highly appreciated for their support.

\section{REFERENCES}

Adugna A, Tesso T, Degu E, Tadesse T, Merga F, Legesse W, Tirfessa A, Kidane H, Wole A \& Daba C (2011) Genotype-by-Enviroment Interaction and Yield Stability Analysis in Finger Millet (Eleusine coracana L. Gaertn) in Ethiopia. American Journal of Plant Sciences 2: 408-415.

Alam SM, Shah SA \& Iqbal MM (2005) Evaluation of method and time of fertilizer application for yield and optimum P-efficiency in wheat. Songklanakarin journal of Science and Technology 27(3): 457-463.

Dixon R C (2003) Foliar fertilization improves nutrient use efficiency. Fluid Journal 11: 22-23.

Hinsinger H (2009) Bioavailability of soil inorganic P in the rhizosphere as affected by root-induced chemical changes: a review. Plant and Soil 237(2): 173-195.

Li F, Pan X, Liu S, Li Y \& Yang F (2007) Effects of phosphorus deficiency stress on root morphology and nutrient absorption of rice cultivars. Acta-Agronomica-Sinica 30: 538-442.

Masinde W, Wesonga J, Ojiewo C, Agong G \& Masuda M (2009) Dynamic soil. Dynamic Plant 7: 16-28.

National Research Council (NRC) (1996) Lost Crops of Africa, Grains. Board on Science and Technology for International Development, National Academy Press, Washington D. C. pp 39-57.

Obaidullah M (2007) Influence of clonal tillers age on growth and yield of inbred and hybrid rice, M.Sc. Thesis. Department of Agron, Sher-e-Bangla Agricultural University, Dhaka, Bangladesh.

Oduori COA (2005) The importance and Research Status of Finger Millet in Africa. A Paper Presented at The McKnight Foundation Collaborative Crop Research Program Workshop on Tef \& Finger Millet: Comparative Genomics of the Chloridoid Cereals at the Biosciences for East and Central Africa (BECA) ILRI, Nairobi, Kenya, 28-30 June, pp. 12.

Okalebo JR, Jutto PM \& Gathera KW (1991) Effect of form and method of phosphate fertilizer application on maize, sorghum and millet growth in semi-arid environment of Kenya. II. Effect of bulrush and finger millet. East African Forestry Journal 55: 239-248. 
Opiyo AM (2004) Effect of nitrogen application on leaf yield and nutritive quality of black nightshade Solanum nigrum L. Outlook on agriculture 33(3): 209-214.

Ozturk L, Eker S, Torun B \& Cakmak I (2005) Variation in Phosphorus Efficiency among 73 Bread and Durum Wheat Genotypes Grown in a Phosphorus-Deficient calcareous Soil. Plant Soil (1): 69-80.

Parmer YS (2007) Effect of nitrogen, phosphorus and biofertilizer application on plant growth and bulb production in tuberose. Haryana Journal of Horticultural Sciences 36(1\&2): 82-85.

Pearse S, Veneklaas J, Cawthray R, Bolland A \& Lambers H (2006) Carboxylate release of wheat, canola and 11 grain legume species as affected by phosphorus status. Plant and Soil 288: 127-139.

Rehman O, Ranjha AM, Saleem SM, \& Khan AA (2004) Phosphorus requirement of wheat using modified Freundlich model in Rasulpur soil series. Pakistan Journal of Agricultural Sciences 41(1-2): 39-46.

Ren AZ, Gao YB \& Zhao F (2007) Response of Neotyphodieum lolii-infected perennial ryegrass to phosphorus deficiency. Plant, Soil and Environment 53(3): 113-119.

Richardson AE \& Mullaney EJ (2009) In: Turner BL, Richardson AE \& Mullaney EJ (eds) Inositol Phosphates: Linking Agriculture and the Environment. CAB International, Wallingford, UK, pp. 304-307.

Shane R \& Lambers D (2005) Physiological traits for crop yield improvement in low N and P environments. Plant and Soil 245: 1-15.

Shen J, Li H, Neumann G \& Zhang F (2005) Nutrient uptake, cluster root formation and exudation of protons and citrate in Lupinus albus as affected by localized supply of phosphorus in a split-root system. Plant Science 168: 837-845.

Wissuwa M, Mazzola M \& Picard C (2009) Novel approaches in plant breeding for rhizosphere-related traits. Plant Soil 321: 409-430.

Yousaf M (2004) Application of Langmuir adsorption isotherm to describe phosphorus adsorption in arid lands soils. Pakistan Journal of Agricultural Sciences 7(1): 43-47. 